\title{
PREPROCESSING STRATEGIES AND SPEECH PERCEPTION IN COCHLEAR IMPLANT USERS
}

\author{
Asha Yathiraj, Ashwini Rao
}

Department of Audiology, All India Institute of Speech and Hearing, Mysore, India

Corresponding author: Asha Yathiraj, Department of Audiology, All India Institute of Speech and Hearing, Mysore, India, email: asha_yathiraj@rediffmail.com

\begin{abstract}
Background: The aim of the study was to investigate whether noise reduction algorithms are beneficial for speech perception in the presence of noise in children using cochlear implants. Further, the study also aimed to determine whether any difference in speech perception existed between different pre-processing strategies such as Adaptive Dynamic Range Optimization (ADRO), Autosensitivity Control (ASC), and the two-stage adaptive beam-forming algorithm (Beam) in different signal-tonoise ratios (SNRs).
\end{abstract}

Material and Method: Speech identification scores of the participants were tested in quiet with the 'Everyday' default setting activated. They were also tested using speech in noise at $+5 \mathrm{~dB}$ and $+10 \mathrm{~dB}$ SNR with ADRO, ASC, and Beam activated. Exactly 17 children using Nucleus cochlear implants for at least 1 year were tested.

Results: A significant difference was found between performance in quiet (in the 'Everyday' default setting) and in the presence of noise (with ADRO, ASC, and Beam). No significant difference was found between the 3 pre-processing strategies at both SNRs and between the 2 SNRs for all 3 strategies.

Conclusions: In conditions where the signal and noise emerge from in front of the listener, no influence of the pre-processing strategies was seen.

Keywords: ADRO • ASC • Beam

\section{ESTRATEGIAS PARA EL PRE-PROCESAMIENTO Y PERCEPCIÓN DEL HABLA ENTRE LOS USUARIOS DE IMPLANTES COCLEARES}

\section{Resumen}

Introducción: El objetivo del proyecto fue estudiar si los algoritmos de la reducción del ruido tienen un efecto positivo en la percepción del habla en ruido en niños con implantes cocleares. Por otra parte, el objetivo era también determinar si existe alguna diferencia en la percepción del habla entre distintas estrategias del pre-procesamiento, tales como el algoritmo ADRO, el ajuste automático de la sensibilidad ASC y el algoritmo de dos etapas de la formación de adaptación de la haz Beam en distintas condiciones de la relación de la señal respecto hacia el ruido.

Materiales y método: Los resultados del reconocimiento del habla de los participantes se han examinado en el silencio, con la configuración por defecto "Everyday". También se han realizado estudios del entendimiento del habla en el ruido para la relación de la señal respecto al ruido $+5 \mathrm{~dB}$ y $+10 \mathrm{~dB}$ utilizando la estrategia ADRO, ASC y Beam. Se han examinado17 niños que utilizan el implante coclear Nucleus al menos desde hace un año.

Resultados: Hemos observado una considerable diferencia entre los resultados en el silencio (configuración "Everyday") y en el ruido (con ADRO, ASC y Beam). No se ha registrado diferencia significativa entre las tres estrategias del pre-tratamiento en ambas situaciones de la relación de la señal respecto al ruido y la diferencia entre estas dos situaciones de la relación de la señal respecto al ruido para todas las tres estrategias.

Conclusión: En las condiciones en las que la señal y el ruido aparecían antes del oyente, no se ha observado ningún efecto de la estrategia del pre-procesamiento.

Palabras clave: ADRO • ASC • Beam 


\title{
СТРАТЕГИИ ПРЕДВАРИТЕЛЬНОЙ ОБРАБОТКИ И ВОСПРИЯТИЯ РЕЧИ СРЕДИ ПОЛЬЗОВАТЕЛЕЙ УЛИТКОВЫХ ИМПЛАНТАТОВ
}

\begin{abstract}
Изложение
Введение: Цель проекта - исследование относительно полезности влияния алгоритмов редукции шума на восприятие речи в шуме у детей с улитковыми имплантатами. Кроме того, цель проекта - это также определение, есть ли какая-нибудь разница в восприятии речи между разными стратегиями предварительной обработки, такими как алгоритм ADRO, автоматическая регулировка чувствительности ASC и двухступенчатый алгоритм адаптивного формирования связки Веат в разных условиях отношения сигнал/шум.
\end{abstract}

Материал и метод: Результаты понимания речи участников были исследованы в тишине, при любой регуляции Everyday?. Были также проведены исследования понимания речи в шуме для отношения сигнал/ шум $+5 \mathrm{~dB}$ и $+10 \mathrm{~dB}$ с использованием стратегии ADRO, ASC и Beam. Были исследованы 17 детей, пользующихся улитковыми имплантатами Nucleus в течение хотя бы одного года.

Результаты: Мы заметили значительную разницу между результатами в тишине (регуляция Еveryday) и в шуме (с ADRO, ASC и Beam). Мы не заметили значительной разницы между тремя стратегиями предварительной обработки в обеих ситуациях отношения сигнал/шум и разницы между этими двумя ситуациями отношения сигнал/шум для каждой из этих трех стратегий.

Итоги: В условиях, в которых у слушателя появлялся сигнал и шум, не замечено никакого влияния стратегии предварительной обработки.

Ключевые слова: ADRO • ASC • Beam

\section{STRATEGIE WSTĘPNEGO PRZETWARZANIA I PERCEPCJA MOWY WŚRÓD UŻYTKOWNIKÓW IMPLANTÓW ŚLIMAKOWYCH}

\section{Streszczenie}

Wprowadzenie: Celem projektu było zbadanie, czy algorytmy redukcji hałasu wpływają korzystnie na percepcję mowy w hałasie u dzieci z implantami ślimakowymi. Ponadto celem projektu było również określenie, czy istnieje jakakolwiek różnica w percepcji mowy pomiędzy różnymi strategiami wstępnego przetwarzania, takimi jak algorytm ADRO, automatyczna regulacja czułości ASC i dwustopniowy algorytm adaptacyjnego kształtowania wiązki Beam w różnych warunkach stosunku sygnału do szumu.

Materiał i metoda: Wyniki rozpoznawania mowy uczestników badano w ciszy, przy domyślnym ustawieniu 'Everyday'. Wykonano także badania rozumienia mowy w szumie dla stosunku sygnału do szumu $+5 \mathrm{~dB}$ i $+10 \mathrm{~dB}$ z wykorzystaniem strategii ADRO, ASC i Beam. Zbadano 17 dzieci używających implantów ślimakowych Nucleus od co najmniej roku.

Wyniki: Zaobserwowaliśmy znaczącą różnicę pomiędzy wynikami w ciszy (w ustawieniu 'Everyday') i w hałasie (z ADRO, ASC i Beam). Nie odnotowano znaczącej różnicy pomiędzy trzema strategiami wstępnego przetwarzania w obydwóch sytuacjach stosunku sygnału do szumu i różnicy pomiędzy tymi dwiema sytuacjami stosunku sygnału do szumu dla każdej z tych 3 strategii.

Wniosek: W warunkach, w których sygnał i hałas pojawiał się przed słuchaczem, żaden wpływ strategii wstępnego przetwarzania nie został zaobserwowany.

Słowa kluczowe: ADRO • ASC • Beam

\section{Background}

Cochlear implant (CI) technology has been found to afford increasingly high levels of speech understanding. Research in the past two decades has shown considerable improvement in speech recognition in quiet in individuals using cochlear implants [1-7]. However, speech perception performance is reported to deteriorate with increasing levels of background noise [5,8]. Difficulty in understanding in the presence of background noise is a reason for dissatisfaction among CI recipients, despite advances in the technology [9]. Therefore, improving speech understanding in challenging environments has remained one of the most important design objectives for new commercial CI systems.

CI manufacturers have focused on developing and refining sound coding strategies to improve performance in adverse listening conditions. The performance in noise has been studied for different speech processing strategies 
employed in different implant systems [10-13]. Several studies have indicated a marked improvement in speech performance in the presence of noise with the use of noise reduction algorithms in cochlear implant users [9,14-16]. Currently available cochlear implant speech processors are equipped with preprocessing strategies [9] and/or external accessories [8] designed to enhance perception in noisy conditions.

A variety of pre-processing strategies to improve speech in noise have been made available in the Nucleus Freedom processor and subsequent models of processors manufactured by Cochlear limited. The pre-processing strategies, known as SmartSounds, represent the four input processing technologies available on the Nucleus Freedom speech processor [Adaptive Dynamic Range Optimization (ADRO), Autosensitivity control (ASC), a two-stage adaptive beam-forming algorithm (Beam), and Whisper] and the five in the CP810 processor (ADRO, ASC, Beam, Whisper, and Zoom). Each of the SmartSound options pre-processes sound in different ways in order to give optimum benefit under different listening environments.

ADRO was reported by Blamey et al. [17] to be an adaptive system that adjusts the channel gains to ensure speech is always delivered at a comfortable listening level despite changing listening situations. According to Dawson et al. [18], the gain does not exceed a specified maximum amount. This maximum gain rule limits the amplification of low-level background noise. Patrick et al. [19] report that ADRO was incorporated into the Nucleus CI system in 2002 as an input signal processing option. However, according to a Cochlear cooperation company report, in the CP810 processor ADRO is incorporated after the filtering process, permitting independent adjustments of each filter band. This is unlike their front-end processing (ASC, Beam, Whisper, and Zoom) that is reported to act on all the electrodes prior to filtering.

James et al. [15] investigated the acceptability and the effect of ADRO on speech perception in nine individuals with cochlear implants, with and without ADRO. Perception of City University of New York (CUNY) sentences, and consonant-nucleus-consonant (CNC) words, were tested in the presence of multi-talker babble with $15 \mathrm{~dB}$ and $10 \mathrm{~dB}$ signal-to-noise ratios (SNRs). The results revealed a significant improvement in speech perception scores with the ADRO programs over the standard. At $50 \mathrm{~dB}$, the mean open set sentence scores in quiet improved by $16 \%$ $(p<0.001)$; at $60 \mathrm{~dB}$ the mean $\mathrm{CNC}$ word score improved by $9.5 \%(p<0.001)$; and at $40 \mathrm{~dB}$ the mean spondee score increased by $20 \%(p<0.05)$. However, no significant difference was noticed between ADRO and the standard program for sentences presented in either noise conditions. The authors opined that continual adjustment of channel gains using ADRO provided improved sound quality and improved speech perception performance. Hence, they reported that ADRO could be a viable alternative to fixed channel gain.

ASC was described by Patrick et al. [19] to be an optional processing scheme that automatically adjusts the sensitivity according to the noise floor, and was designed to reduce the impact of background noise. This input preprocessing strategy was observed to provide substantial benefit in speech perception in noise. The effect of ASC on speech performance in quiet and noisy situations was evaluated in 10 individuals using the Nucleus Freedom implant by Wolfe et al. [20]. Speech recognition with ASC with noise at $65 \mathrm{dBA}, 70 \mathrm{dBA}$, and $74 \mathrm{dBA}$ was found to be significantly better with no ASC, as well as with ASC with noise at $75 \mathrm{dBA}$.

Beam was introduced in the Nucleus Freedom speech processor in 2005, as reported by Spriet et al. [21]. According to them, Beam combined information from both a front directional and a rear omnidirectional microphone on the processor. The directional microphone system was reported to contain two ports separated by $0.7 \mathrm{~cm}$. The rear omnidirectional microphone was separated from the front port of the directional microphone by $1.9 \mathrm{~cm}$. According to Patrick et al. [19], Beam works in two phases: the first is a directional operation and the second effects an adaptive noise cancellation operation. Beam was recommended for specific listening situations in noise where the sound source is in front of an individual and the interfering noise sources are at the sides and/or behind.

As early as 1995, Van Hoesel and Clark used a bilateral two-microphone adaptive beamformer to evaluate the effect of noise reduction algorithms in cochlear implants. They demonstrated a directional gain of about $10 \mathrm{~dB}$ with Nucleus 22 cochlear implantees. The results revealed that the two-microphone and two-stage adaptive filtering strategy lead to very significant improvements in CVC identification and speech recognition threshold in the presence of steady and non-steady noise. With the adaptive beamformer, a score of $80 \%$ was obtained in quiet and $30 \%$ in noise. The authors concluded that for speech-in-noise applications, a directional microphone would perform better than an omnidirectional one.

Gifford and Revitt [16] assessed the speech perception of 34 adults aged 18 to 90 years using cochlear implants, 20 of whom were Cochlear Ltd recipients. The participants were evaluated in the presence of R-SPACE noise in order to determine whether commercially available preprocessing strategies and/or external accessories yielded improved sentence recognition in noise. Adaptive speech recognition thresholds with the hearing-in-noise test sentences were obtained for the participants with their preferred listening programs as well as with the addition of the Beam option. In addition, 16 of the 20 Cochlear Ltd subjects were reassessed to obtain their speech recognition thresholds in noise using a combination of noise reduction algorithms: ADRO (Everyday SmartSound environment), ADRO+ASC (Noise SmartSound environment), and ADRO+ASC+Beam (Focus SmartSound environment). Statistical analysis indicated that both the Noise and Focus SmartSound environment resulted in significant improvements in SRT in noise when compared to the Everyday program. The Focus yielded equivalent or better performance in noise compared to the Noise program. The degree of improvement in SNR ranged from 0 to $7.33 \mathrm{~dB}$.

Brockmeyer and Potts [9] measured speech recognition of 27 unilateral and three bilateral adult Nucleus Freedom CI recipients in R-SPACE with four processing options: 
standard dual-port directional, ADRO, ASC, and Beam at two noise levels. The participants' everyday program (with no additional processing) was used as the standard dualport directional program while ADRO, ASC, and Beam were added individually to the standard dual-port directional program to create a total of four programs. Hearing-in-noise test sentences were presented at $0^{\circ}$ azimuth with R-SPACE restaurant noise at 60 and $70 \mathrm{~dB}$ SPL. The results showed that in $60 \mathrm{~dB}$ SPL noise, standard dual-port directional processing resulted in a mean reception threshold for sentences of $10.8 \mathrm{~dB}$. The poorest performance was with ADRO, with a mean reception threshold of $12.8 \mathrm{~dB}$. ASC and Beam processing showed an improvement in reception threshold relative to the standard dual-port directional and ADRO processing, with means of 9.5 and $8.3 \mathrm{~dB}$, respectively. In the $70 \mathrm{~dB}$ SPL noise, ASC (10.2) and Beam (12.2) had significantly better mean reception thresholds compared to the standard dual-port directional processing (15.6) and ADRO (15). Comparison of noise levels showed that the standard dual-port directional and Beam processing resulted in significantly poorer reception threshold in $70 \mathrm{~dB}$ SPL noise compared to the performance with these processing conditions in $60 \mathrm{~dB}$ SPL noise. The authors suggested that the use of processing options involving noise reduction would improve a CI recipient's ability to understand speech in a noisy environment.

The effect of front-end processing on cochlear implant performance of children aged 4 to 12 years was evaluated by Wolfe et al. [22]. The authors investigated the potential benefits of ADRO compared to ASC+ADRO for 11 children using unilateral or bilateral Nucleus 5/Freedom cochlear implants. Speech perception of PBK-50 monosyllabic words in quiet and BKB-SIN sentences in noise was measured for each participant. In the quiet situation the participants obtained scores of $90 \%$ or higher. In noise, sentence perception performance in the ASC+ADRO condition was significantly better than with ADRO alone. The average speech-in-noise threshold was 8.9 and 5.5 for ADRO and ADRO+ASC respectively. The authors reported considerable improvement in speech in noise with a combination than with a single strategy.

The literature on noise reduction algorithms in individuals with cochlear implants has indicated benefit in speech understanding under adverse listening conditions. However, research has mainly focused on studying the impact of isolated strategies $[15,21]$ or comparing combinations of preprocessing such as ADRO+ASC or ASC+Beam [16] This makes it difficult to compare the impact of one strategy over the other. Therefore, it is necessary to evaluate the effectiveness of individual pre-processing strategies on speech perception in CI users. There is also a need to determine how the different strategies function in the presence of different SNRs, which would shed light on whether the strategies function similarly or differently with varying SNRs. In addition, the majority of studies reported in the literature have been based on small samples of CI users. There is a need to check the utility of different preprocessing strategies on a larger population. Further, most of the reported literature on the utility of noise reduction algorithms has been evaluated on post-lingual adults $[9,21]$. Such data may not necessarily reflect the effectiveness on children. Post-lingual adults have the capacity to utilize redundant cues in order to perceive acoustical signals that they may miss under adverse listening conditions. On the other hand, children without past linguistic exposure are less able to use these redundant cues.

Thus, there is a need to study the impact of noise reduction algorithms in children. The main aim of the present study was to investigate whether noise reduction algorithms were beneficial for the perception of speech in the presence of noise in children using cochlear implants. Further, the study also aimed to determine whether any difference in speech perception existed between the different noise reduction algorithms such as ADRO, ASC, and Beam in different SNRs. Such information would serve as a basis for recommending the use of specific noise reduction algorithms in specific listening conditions.

\section{Material and Method}

\section{Participants}

Seventeen children with congenital hearing impairment and who had used Nucleus cochlear implants for at least 1 year with stable maps participated in the study. The children, aged 5 to 13 (mean age 8 years 7 months) had been exposed to Kannada $(\mathrm{N}=16)$ or Indian English $(\mathrm{N}=2)$ from early childhood, the former being a language spoken in South India. They used Nucleus 24/512/Freedom implants with SPrint $(\mathrm{N}=5)$, Freedom $(\mathrm{N}=6)$, or $\mathrm{CP} 810(\mathrm{~N}=6)$ sound processors which had facilities to activate various pre-processing strategies. All participants used the ACE speech coding strategy. The participants had aided thresholds within the speech spectrum. All but one had speech identification scores greater than $50 \%$ in quiet, measured either using the 'Kannada phonemically balanced word identification test' [23] or the 'Monosyllable speech identification test in English for Indian children' [24]. (The aided speech identification score of the exception, measured using different lists of the same tests, was $44 \%$ in quiet.) The open-set speech identification scores in quiet of the participants, with their regularly used settings, ranged from $44 \%(11 / 25)$ to $88 \%$ (22 out of a maximum possible 25$)$, with the mean being $69.4 \%$ (16.35). None of the participants had any neurological or otological symptoms other than hearing impairment. The participants had a minimum of 6 months experience with hearing aids prior to the use of implants. Only one participant had no exposure to a hearing aid before undergoing implantation (Table 1).

Prior to the commencement of the study, informed consent was taken from the caregivers of the participants. It was also ensured that the recommendations of the 'Ethical Guidelines for Bio-Behavioural Research Involving Human Subjects' [25] of the All India Institute of Speech and Hearing were adhered to.

\section{Test equipment and material}

Custom Sound version 3.2 (Cochlear Ltd) was used to program the speech processor of the participants. The programming was carried out by two audiologists who had over 8 years of experience doing cochlear implant mapping. The speech processor of each participant was hardwired through a programming interface (Portable Programming System/ Programming Pod, depending on the type of the processor) to a personal computer loaded with 
Table 1. Demographic details of the participants

\begin{tabular}{|c|c|c|c|c|c|c|c|}
\hline Client no. & Age in years & Gender & Implant & Speech processor & $\begin{array}{c}\text { Experience } \\
\text { with } \mathrm{Cl} \\
\text { (in years) }\end{array}$ & $\begin{array}{l}\text { Years of initial } \\
\text { hearing aid } \\
\text { usage }\end{array}$ & $\begin{array}{c}\text { Open set SIS } \\
\text { in quiet } \\
\text { (max }=25)\end{array}$ \\
\hline 1. & 5 & $\mathrm{~F}$ & Freedom CA & CP810 & 2 & 1 & $80 \%(20)$ \\
\hline 2. & 8 & M & $\mathrm{Cl} 512$ & CP810 & 1 & 3 & $60 \%(15)$ \\
\hline 3. & 5 & $\mathrm{~F}$ & $\mathrm{Cl} 512$ & CP810 & 2 & $1 ; 5$ & $80 \%(20)$ \\
\hline 4. & 6 & M & $\mathrm{Cl} 512$ & CP810 & $1 ; 4$ & 2 & $80 \%(20)$ \\
\hline 5. & 13 & $\mathrm{~F}$ & Nucleus 24 & CP810 & 7 & 1 & $88 \%(22)$ \\
\hline 6. & 6 & $\mathrm{~F}$ & $\mathrm{Cl} 512$ & CP810 & 1 & 2 & $56 \%(14)$ \\
\hline 7. & 9 & $\mathrm{~F}$ & Nucleus 24 & Freedom & 1 & 1 & $80 \%(20)$ \\
\hline 8. & 12 & $\mathrm{~F}$ & Freedom CA & Freedom & 4 & 4 & $72 \%(18)$ \\
\hline 9. & 10 & $\mathrm{~F}$ & Freedom CA & Freedom & 4 & 1 & $44 \%(11)$ \\
\hline 10. & 6 & $\mathrm{~F}$ & Freedom CA & Freedom & 2 & 1 & $72 \%(18)$ \\
\hline 11. & 9 & M & Nucleus 24 & Freedom & 4 & $2 ; 6$ & $68 \%(17)$ \\
\hline 12. & 7 & M & Freedom CA & Freedom & 3 & $2 ; 6$ & $56 \%(14)$ \\
\hline 13. & 12 & $\mathrm{~F}$ & Nucleus 24 & SPrint & 3 & $1 ; 6$ & $68 \%(17)$ \\
\hline 14. & 12 & $\mathrm{~F}$ & Nucleus 24 & SPrint & 6 & $1 ; 6$ & $76 \%$ (19) \\
\hline 15. & 10 & $\mathrm{~F}$ & Nucleus 24 & SPrint & $4 ; 5$ & $<1$ & $64 \%(16)$ \\
\hline 16. & 9 & M & Nucleus 24 & SPrint & 4 & 1 & $72 \%(18)$ \\
\hline 17. & 13 & $\mathrm{~F}$ & Nucleus 24 & SPrint & 4 & 3 & $64 \%(16)$ \\
\hline
\end{tabular}

$\mathrm{CI}$ - cochlear implant; SIS - speech identification score.

the Custom Sound software. The same software was used to implement preprocessing strategies in the speech processor of all the participants along with their standard map.

A calibrated double channel diagnostic audiometer, Orbiter 922 (version 2), was used to carry out the speech perception tests. Through a calibrated loudspeaker, noise and speech were presented at different SNRs.

The participants who spoke Kannada $(\mathrm{N}=15)$ were evaluated on the 'Kannada phonemically balanced word identification test' [23] and those who spoke Indian English $(\mathrm{N}=2)$ were evaluated using the 'Monosyllable speech identification test in English for Indian children' developed by Rout [24]. The Kannada test had 4 lists of 25 words familiar to children aged 5 years and above. The material within each list was randomized to avoid word familiarity effects which led to the formation of 8 lists. The Rout test consists of 2 lists each having 25 phonemically balanced words with norms established on children. These words were randomized to form additional lists. A personal computer, connected to the auxiliary input of the audiometer, was used to present the recorded speech material.

\section{Test environment}

The testing procedure was carried out in an air-conditioned sound-treated suite. The permissible noise limits in the test facility were to ANSI standards [26].

\section{Procedure}

Aided warble tone thresholds were obtained at octaves and mid octaves $(250 \mathrm{~Hz}$ to $8 \mathrm{kHz})$ using a modified Hughson-Westlake procedure. The measurement was carried out with the participants seated 1 meter from the loudspeaker which was placed at $0^{\circ}$ azimuth. Further testing was done only if the aided thresholds were found to be well within the speech spectrum.

The aided speech identification performance of the participants was tested under four conditions which included the 'Everyday' default setting and the three pre-processing strategies (ADRO, ASC, and Beam). The 'Everyday' default setting was tested in quiet and the three pre-processing strategies were tested in two signal-to-noise ratios $(+5 \mathrm{~dB}$ and $+10 \mathrm{~dB})$ using speech noise. The participants' 'Everyday' default setting varied depending on the type of speech processor they used. For the CP810 processor, the default setting was ADRO+ASC, whereas for the Freedom and SPrint processors, the default setting was ADRO. The speech identification abilities of the participants were tested with the speech processor activated with one algorithm at a time. The recorded speech tests as well as the speech noise were presented through the same loudspeaker at $0^{\circ}$ azimuth.

Speech identification testing was done with the recorded speech test material presented at $45 \mathrm{~dB} \mathrm{HL}$, which 
Table 2. Mean, SD, and confidence intervals for 15 participants

\begin{tabular}{cccccccccc}
\hline Strategy & SNR & \multicolumn{2}{c}{ Mean } & SD & Lower bound & Upper bound & N \\
\hline Everyday (default) & Quiet & 16.66 & $(66.64 \%)$ & 3.81 & 15.15 & $(60.6 \%)$ & 19.12 & $(76.48 \%)$ & 15 \\
\hline \multirow{2}{*}{ ADRO } & $+5 \mathrm{~dB}$ & 12.66 & $(50.64 \%)$ & 4.26 & 11.02 & $(44.8 \%)$ & 15.35 & $(61.4 \%)$ & 15 \\
\cline { 2 - 9 } & $+10 \mathrm{~dB}$ & 11.86 & $(47.44 \%)$ & 4.35 & 10.87 & $(43.48 \%)$ & 14.75 & $(59 \%)$ & 15 \\
\hline \multirow{2}{*}{ ASC } & $+5 \mathrm{~dB}$ & 12.73 & $(50.92 \%)$ & 4.12 & 11.49 & $(45.96 \%)$ & 15.14 & $(60.56 \%)$ & 15 \\
\cline { 2 - 10 } & $+10 \mathrm{~dB}$ & 12.86 & $(51.44 \%)$ & 4.47 & 10.38 & $(41.52 \%)$ & 14.63 & $(58.52 \%)$ & 15 \\
\hline \multirow{2}{*}{ Beam } & $+5 \mathrm{~dB}$ & 13.10 & $(52.4 \%)$ & 3.69 & 10.80 & $(43.2 \%)$ & 15.80 & $(63.2 \%)$ & 10 \\
\cline { 2 - 9 } & $+10 \mathrm{~dB}$ & 14.40 & $(57.6 \%)$ & 4.62 & 11.80 & $(47.2 \%)$ & 16.80 & $(67.2 \%)$ & 10 \\
\hline
\end{tabular}

Maximum score $=25$.

Table 3. Mean, SD, and confidence intervals for 17 participants

\begin{tabular}{cccccccccc}
\hline Strategy & SNR & \multicolumn{2}{c}{ Mean } & SD & \multicolumn{2}{c}{ Lower bound } & \multicolumn{2}{c}{ Upper bound } & N \\
\hline Everyday (default) & Quiet & 17.35 & $(69.4 \%)$ & 2.8 & 15.4 & $(61.6 \%) 4$ & 19.15 & $(76.6 \%)$ & 17 \\
\hline \multirow{2}{*}{ ADRO } & $+5 \mathrm{~dB}$ & 13 & $(52 \%)$ & 3.12 & 11.84 & $(47.36 \%)$ & 15.06 & $(60.24 \%)$ & 17 \\
\cline { 2 - 10 } & $+10 \mathrm{~dB}$ & 12.23 & $(48.92 \%)$ & 3.85 & 10.93 & $43.72 \%)$ & 14.55 & $(58.2 \%)$ & 17 \\
\hline \multirow{2}{*}{ ASC } & $+5 \mathrm{~dB}$ & 12.76 & $(51.04 \%)$ & 4.12 & 11.59 & $(46.36 \%)$ & 15.25 & $(61 \%)$ & 17 \\
\cline { 2 - 10 } & $+10 \mathrm{~dB}$ & 13.05 & $(52.2 \%)$ & 3.67 & 11.48 & $(45.92 \%)$ & 15.12 & $(60.48 \%)$ & 17 \\
\hline \multirow{2}{*}{ Beam } & $+5 \mathrm{~dB}$ & 13.50 & $(54 \%)$ & 3.55 & 10.97 & $(43.88 \%)$ & 15.53 & $(62.12 \%)$ & 12 \\
\cline { 2 - 10 } & $+10 \mathrm{~dB}$ & 14.47 & $(57.88 \%)$ & 4.25 & 12.05 & $(48.2 \%)$ & 16.63 & $(66.52 \%)$ & 12 \\
\hline
\end{tabular}

Maximum score $=25$.

corresponds to a normal conversational level [27]. The stimuli were played using a personal computer connected to the auxiliary input of the audiometer. Speech noise was generated from the audiometer. All the participants were initially tested in quiet, followed by the $+5 \mathrm{~dB}$ SNR and $+10 \mathrm{~dB}$ SNR noise conditions. The order in which they were tested with the pre-processing strategies (ADRO, ASC, and Beam) was randomized to avoid any test order effect. The participants were instructed to listen to the speech stimuli and give an oral response. Written responses were obtained if a child had misarticulation. All testing was done within one session. Breaks were given if a child was found to be restless. Appropriate reinforcements were provided to the participants. Test-retest reliability was determined by repeating the procedure on two participants after an interval of 2 months.

The obtained scores were tabulated and analyzed to determine the performance of individuals using cochlear implants in quiet and in the presence of noise across the three pre-processing strategies (ADRO, ASC, and Beam).

\section{Results}

The speech identification scores obtained by the 18 participants were analysed using SPSS software (version 18). The analysis was done for their responses in quiet with them using their 'Everyday' default setting. Additionally, their responses with the activation of three pre-processing strategies (ADRO, ASC, and Beam) under two noise conditions ( $+5 \mathrm{~dB}$ and $+10 \mathrm{~dB}$ SNR) were analysed. Initially, the data were analysed without and with the scores of the two children who were tested in Indian English. This was done to check if the language of evaluation made a difference in the statistical output so as to decide whether the scores of the two children should be included or excluded from further analyses. Inclusion of the two Indian English speaking children was necessary to statistically determine the influence of certain parameters such as the effect of microphone directionality on the perception of speech.

Table 2 shows the mean and standard deviation (SD) of the speech identification scores of the 15 Kannada speaking participants in quiet and noise, at two SNRs across the three processing strategies. Of the 15 participants only 10 had provision for Beam in their processor. Likewise, Table 3 depicts the score of all 17 participants, which included the 15 Kannada speaking children and the two Indian English speaking children. Among the 17 participants, Beam could be activated in 12 of them.

Further, Mauchly's test of sphericity was used to check if the data obtained from the 15 children (excluding the 2 Indian English speaking children) and the 17 participants (including the 2 Indian English speaking children) met the assumptions required to carry out the analysis of variance. The results of the Mauchly's test showed that the sphericity was assumed in both data sets $(\mathrm{W}=1, p>0.05)$. Hence, the assumptions to carry out ANOVA were satisfied in both sets of data. Additionally, it was found that the mean scores of 


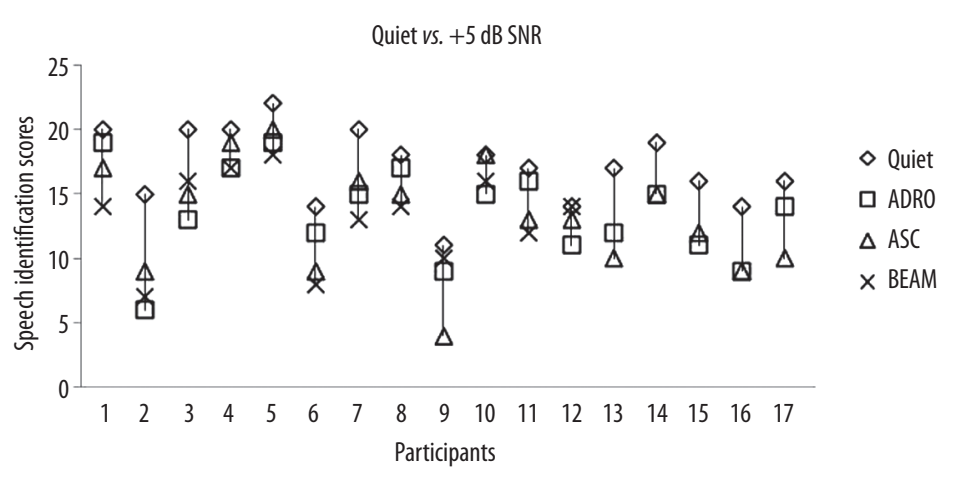

Figure 1. Speech identification scores of participants in quiet and at +5 dB SNR across pre-processing strategies

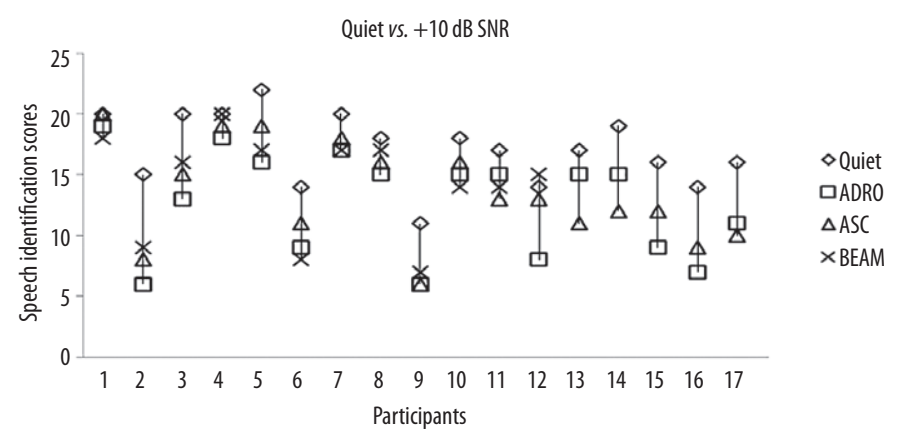

Figure 2. Speech identification scores of participants in quiet and at +10 $\mathrm{dB}$ SNR across pre-processing strategies

the participants without and with the addition of the two Indian English speaking children had similar confidence intervals (Tables 2 and 3). This was observed for all three noise conditions (quiet, $+5 \mathrm{~dB} \mathrm{SNR}$, and $+10 \mathrm{~dB} \mathrm{SNR}$ ) and 3 pre-processing strategies (ADRO, ASC, and Beam).

Thus, comparison of the analysis without and with the two Indian English speaking children revealed that there were only marginal differences in the mean and SD values, sphericity was met in both analyses, and there was no significant difference between the mean scores. This indicated that the inclusion of the scores of the two Indian English speaking children did not alter the results. Hence, all further analyses were carried out with the scores of all 17 participants grouped (15 Kannada and 2 English speakers). Thus, the data were analysed for the 17 participants to compare the speech identification scores without and with the presence of noise; to compare the speech identification scores across the three pre-processing strategies; compare the effect of the two SNRs; and compare the speech identification scores as function of microphone directionality.

Figures 1 and 2 depict the individual raw speech identification scores of the 18 participants in the quiet condition with them using their 'Everyday' default setting and for the three noise reduction algorithms (ADRO, ASC, Beam). Figure 1 shows performance at $+5 \mathrm{~dB}$ SNR and Figure 2 at $+10 \mathrm{~dB}$ SNR. Participants 1 to 6 were the CP810 users, 7 to 12 were Freedom users, and 13 to 17 were SPrint users.

Comparison of scores between default setting in quiet and pre-processing strategies

To compare the performance of the participants in quiet with their performance in noise with different pre-processing algorithms activated, one-way repeated measure ANOVA and paired $t$-test were used. One-way repeated measures ANOVA was used while analysing scores obtained on two of the pre-processing strategies (ADRO and ASC) that had 18 participants. Due to the unequal number of participants using Beam and the other two strategies, Beam could not be analysed using ANOVA. Hence, paired $t$-test (2 tailed) was used when analysing data of Beam that was obtained only from 12 participants.

One-way repeated measures ANOVA with two pre-processing strategies combined (ADRO and ASC) as well as the SNRs combined, a significant main effect was seen for the 17 participants $[F(1,32)=1.215, p<0.05]$. One-way ANOVAs done for each of the SNRs also revealed a similar significant main effect for the $+5 \mathrm{~dB}$ SNR condition $[\mathrm{F}(3,32)=1.109, p<0.05]$ and the $+10 \mathrm{~dB}$ SNR condition $[\mathrm{F}(3,32)=3.45, p<0.05]$.

The output from the one-way ANOVA was analysed using the Bonferroni multiple comparison test. This was done to check if there existed any significant difference between the scores obtained in the quiet condition and with ADRO and ASC activated. The pair-wise comparison revealed that there was a significant difference between the scores in quiet with the participants using their default settings and in the presence of noise (with SNRs combined) for ADRO $(p<0.01)$ and ASC $(p<0.01)$. Also, at each of the SNRs, the pair-wise comparison between the scores obtained in quiet and the two algorithms were statistically significant at the 0.01 level.

The paired $t$-test carried out to check the difference in scores obtained in quiet with that obtained with Beam for the 12 participants was statistically significant. This 
significant difference was observed for the $+5 \mathrm{~dB}$ SNR condition $[\mathrm{t}(11)=6, p<0.01]$ and $+10 \mathrm{~dB}$ SNR condition $[\mathrm{t}(11)=4.78, p<0.01]$.

\section{Comparison of scores across the pre-processing strategies}

Two-way repeated measure ANOVA was carried out to check the impact of ADRO and ASC across the two SNRs $(+5 \mathrm{~dB}$ and $+10 \mathrm{~dB})$. As mentioned earlier, the scores obtained with the participants using Beam could not be tested using ANOVA as this algorithm could be activated on only 12 of the 17 participants. The 2 -way repeated measure ANOVA (2 algorithms $\times 2$ SNRs) indicated that there was no significant main effect $[\mathrm{F}(1,32)=0.08, p>0.05]$ when the two SNRs were combined. Since no significant main effect was seen and no interaction between the two preprocessing strategies and the two SNRs, no further analysis was carried out.

To compare the scores obtained using Beam with ADRO and ASC, an independent $t$-test was carried out. The results of the $t$-test revealed that there was no significant difference in performance between ADRO and Beam $[t(56)=-0.375$, $p>0.05]$ and between ASC and Beam $(\mathrm{t}(56)=-0.483$, $p>0.05$ ] with the two SNRs combined. Similarly, there were no significant differences seen at each of the SNRs.

\section{Comparison of scores across SNRs}

Further, the comparison of scores between the SNRs for each noise reduction algorithm was evaluated using twoway repeated measure ANOVA. The results showed that there was no significant difference in performance between SNRs for ADRO $[\mathrm{F}(1,32)=0.065, p>0.05]$ and ASC $[\mathrm{F}(1,32)=0.145, p>0.05]$. Further, a paired $t$-test showed that there was no significant difference in scores obtained using Beam between the 2 SNRs [ $\mathrm{t}(11)=-1.476, p>0.05]$.

\section{Effect of microphone directionality on speech identification}

In addition, the data were analysed to see the effect of microphone directionality on speech perception. This was done only for those using the Beam algorithm since its functioning is based on the responses of the two microphones that are utilised. The data were compared between scores obtained from participants using CP810 and Freedom speech processors as the former utilised two omnidirectional microphones and the latter used one omnidirectional and one directional microphone. Independent $t$-test showed that there was no statistically significant difference in scores between the two processors using different microphone directionality $[\mathrm{t}(22)=0.263, p>0.05]$.

\section{Comparison of scores across speech processors}

Further, to compare the scores as a function of microphone directionality, the scores were compared across speech processors (CP810, Freedom, SPrint). Each type of processor had six participants. Kruskal-Wallis test revealed that there was no significant difference in scores across the processors.

Test-retest reliability was ensured by carrying out the testing procedure on two participants. The scores did not vary when the test procedure was repeated after an interval of 2 months.

\section{Discussion}

Comparison of speech identification scores obtained in quiet and in the presence of noise

Depending on the SNR and the noise reduction algorithm, results indicated a variable reduction in scores. The scores obtained in quiet, with the participants using their default 'Everyday' settings, served as a baseline to compare the performance in the presence of noise with different noise reduction algorithms activated. The significant drop in scores in the presence of noise with all three noise reduction algorithms indicates that, despite the use of these algorithms, their performance declined. As can be seen in Table 3, the mean decline in scored varied from $5.12(17.4 \%)$ to 2.88 (11.52\%).

The drop in scores with the noise reduction algorithms in the presence of noise is comparable to, or less than, what has been reported to occur in normal hearing individuals or in hearing aid users at similar SNRs. Finitzo-Hieber and Tillman [28] reported that in children with mild hearing impairment who wore hearing aids, at $+6 \mathrm{~dB}$ SNR with a 0.4 reverberation condition, speech identification scores reduce by $21.8 \%$ from a mean score of $74 \%$. Similarly, Johnson [29] reported that in normal hearing children and adults, with an input signal of $40 \mathrm{~dB}$ SL, scores dropped by $12.5 \%$ from a mean score of $67.4 \%$ with the addition of $\mathrm{a}+13 \mathrm{~dB}$ SNR in a reverberant condition.

Thus, it can be inferred that the pre-processing strategies do not enable CI users to hear speech signals in a noisy situation similar to what they hear in quiet situations. However, the difficulty that they face in noisy situations is akin to, or less than, what normal hearing individuals or those with mild hearing loss probably face.

Studies reported in the literature regarding responses with ADRO indicate that the difference in scores without and with noise is far larger than what has been found in the current study. James et al. [15] reported that the percentage drop in scores with ADRO was approximately $60 \%$ at $+10 \mathrm{~dB}$ SNR and $20 \%$ at $+15 \mathrm{~dB}$ SNR (with the signal presented at $70 \mathrm{~dB}$ SPL). Such a large decline in scores was not evident in the present study. The variation in findings between the study by James et al. [15] and the current study cannot be attributed to the type of processers/ microphones used. While the former study used SPrint or ESPrit which utilise directional microphones, the present study used a combination of SPrint, Freedom, and CP810 processors. The former processor had directional microphones and the latter two had a combination of directional and omnidirectional microphones. However, statistically no difference was noted between the different types of processors having different microphones. Possible reasons for the variation could be the different stimulation rates $(200 \mathrm{~Hz}$ to $900 \mathrm{~Hz})$ used, implementation of ADRO, variation in the frequency allocation table, and the IIDR used by James et al. [15] which might all have resulted in poorer scores. Dawson et al. [18], similar to the present study, did not find a very large reduction in speech 
identification scores with the addition of noise. This reduction was less with the use of ADRO than with the use of a standard program. However, besides presenting the test stimuli with and without noise, they also varied the input level of the signal. In quiet, the signal was presented at $50 \mathrm{~dB}$ SPL and in the presence of noise it was presented at $65 \mathrm{~dB}$ SPL. This makes it difficult to draw any direct conclusion about the difference in performance without and with noise. The study however did demonstrate that both in quiet and in a noisy situation, ADRO was effective in significantly improving speech identification scores.

Comparison of the scores across the three pre-processing strategies

The study showed that there was no significant difference between ADRO, ASC, and Beam strategies. This is reflected in the individual scores of the participants in Figures 1 and 2 and was evident for both the SNRs that were studied.

Studies demonstrating improvement in speech identification with ASC or Beam in isolation is sparse. Brockmeyer and Potts [9] noted that standard dual-port directional program and ADRO had significantly poorer reception thresholds for sentences compared to ASC and Beam. Such differences in the programs were not observed in the present study. Variations in the procedure used for the presentation of the noise could have led to a difference between the findings of the present study and those of Brockmeyer and Potts [9]. The present study had an easier condition in which the signal was presented from only one direction, while in the latter study the noise was presented from 8 speakers placed around the participants.

Thus, it is possible that only in listening conditions that are more difficult than what has been used in the present study, there may be a perceptual variation in the different pre-processing strategies. However, in a situation where noise and speech signals are generated from the front, which could occur in a real life situation, no difference in performance would probably occur by varying the preprocessing strategy.

\section{Change in SNR from $+5 \mathrm{~dB}$ to $+10 \mathrm{~dB}$}

Here, no significant change in performance was seen in the current study with all three pre-processing strategies. This indicates that with higher noise levels (40 dB HL), the device enabled the individuals to continue perceiving speech in a similar manner as with a lower noise level ( $35 \mathrm{~dB} \mathrm{HL})$. However, in normal hearing children, with an almost similar increase in noise levels $(+12 \mathrm{~dB}$ to $+6 \mathrm{~dB})$, a drop in performance by $11.4 \%$ has been reported by Finitzo-Hieber and Tillman [28]. In the present study, the maximum reduction in performance with increase in noise was just $4 \%$. From this finding, it can be stated that pre-processing strategies enable children using CIs to not be adversely affected by noise to the same extent as that which occurs in normal hearing children.

\section{Effect of microphone directionality}

The results of the current study revealed that there was no effect of microphone directionality. Regardless of whether an individual used a directional, omnidirectional, or a combination of microphones, the responses were similar. This lack of difference probably relies on both the signal and the noise arriving from the front of the listener.

According to Wolfe et al. [22], a significant mean improvement of $12 \%$ was noted with the CP810 over the Freedom processor. However, the same was not reflected in the present study. Due to a lack of detail regarding how the 2011 study was carried out, the reason for the lack of consensus between the two studies cannot be specified.

Nevertheless, from the present study it can be inferred that when the noise and signal come from the same direction, any pre-processing strategy (ADRO, ASC, or Beam) can be utilised. These pre-processing strategies perform in a similar manner at a low $(+5 \mathrm{~dB})$ or higher $(+10 \mathrm{~dB})$ SNR. Directionality of the microphone is found not to have an impact under such conditions.

\section{Conclusions}

From the findings of the study on 17 participants using CP810, Freedom, and SPrint processors, it is evident that in the presence of noise their speech identification scores reduced when compared to their performance in quiet. This reduction was evident across all three pre-processing strategies (ADRO, ASC, and BEAM) at the two SNRs $(+5 \mathrm{~dB}$ and $+10 \mathrm{~dB})$ that were studied. However, the difficulty that the participants had in the presence of noise was similar to, or less than, what normal hearing individuals or those with mild hearing loss were reported to have.

No significant difference in speech identification scores was seen between the three pre-processing strategies studied. Such results would probably occur only in situations where the noise and speech signals are generated from in front of the listener. Additionally, the scores did not vary across the two SNRs that were studied for any of the preprocessing strategies. This highlights that cochlear implant users with pre-processing strategies activated are not as adversely affected by the presence of noise as normal hearing individuals. This effect may occur only when the noise levels do not vary considerably. The study also found that when noise and speech are presented from the front of CI users, it did not matter whether they use processors with directional, omnidirectional, or a combination of directional and omnidirectional microphones.

From the findings of the study, recommendations can be made regarding the type of pre-processing strategy that should be used in typical listening situations when the stimuli and noise arise from the front of the listener. The study also highlights the effect of microphone directionality on speech perception in the presence of noise. 
1. Tyler RS, Moore BC. Consonant recognition by some of the better cochlear-implant patients. J Acoust Soc Am, 1992; 92: 3068-77.

2. Skinner MW, Clarke GM, Whitford LA et al. Evaluation of a new spectral peak coding strategy for the Nucleus 22 channel cochlear implant system. Am J Otolaryngol, 1994; 15: 15-27.

3. Skinner MW, Holden LK, Holden TA et al. Speech recognition as simulated soft, conversational, and raised-to-loud vocal efforts by adults with cochlear implants. J Acoust Soc Am, 1997; 101: 3766-82.

4. Rubinstein JT, Parkinson WS, Lowder MW, Gantz BJ, Nadol JB, Tyler RS. Single-channel to multichannel conversions in adult cochlear implant subjects. Am J Otolaryngol, 1998; 19: 461-66.

5. Fetterman BL, Domico EH. Speech recognition in back-ground noise of cochlear implant patients. J Otolaryngol Head Neck Surg, 2002; 126: 257-63.

6. Firszt JB, Holden LK, Skinner MW et al. Recognition of speech presented at soft to loud levels by adult cochlear implant recipients of three cochlear implant systems. Ear Hear, 2004; 25: 375-87.

7. Spahr AJ, Dorman MF. Performance of subjects fit with the Advanced Bionics CII and Nucleus 3G cochlear implant devices. Arch Otolaryngol Head Neck Surg, 2004; 130: 624-28.

8. Schafer EC, Thibodeau LM. Speech recognition abilities of adults using CIs interfaced with FM systems. J Am Acad Audiol, 2004; 15: 678-91.

9. Brockmeyer AM, Potts LG. Evaluation of different signal processing options in unilateral and bilateral cochlear freedom implant recipients using R-Space background noise. J Am Acad Audiol, 2011; 22: 65-80.

10. Hochberg I, Boothroyd A, Weiss M, Hellman S. Effects of noise and noise suppression on speech perception by cochlear implant users. Ear Hear, 1992; 13: 263-71.

11. Skinner MW, Holden LK, Holden TA. Effect of frequency boundary assignment on speech recognition with the Speak speech-coding strategy. Annals Otol, Rhinol Laryngol Suppl, 1995; 166: 307-11.

12. Kiefer J, Muller J, Pfennigdorff T et al. Speech understanding in quiet and in noise with the CIS speech coding strategy (MED-EL Combi-40) compared to the multipeak and spectral peak strategies (Nucleus). J Otorhinolaryngol Spec, 1996; 58: 127-35.

13. Parkinson AJ, Parkinson WS, Tyler RS, Lowder MW, Gantz BJ. Speech perception performance in experienced cochlearimplant patients receiving the SPEAK processing strategy in the Nucleus Spectra-22 cochlear implant. J Speech Lang Hear Res, 1998; 41(5): 1073-87.
14. Van Hoesel RJ, Clark GM. Evaluation of a portable two-microphone adaptive beamforming speech processor with cochlear implant patients. J Acoust Soc Am,1995; 97: 2498-503.

15. James CJ, Blamey PJ, Martin L, Swanson B, Just Y, Macfarlane D. Adaptive dynamic range optimization for cochlear implants: A preliminary study. Ear Hear, 2002; 23: 49S-58S.

16. Gifford RH, Revitt L J. Speech Perception for Adult Cochlear Implant Recipients in a Realistic Background Noise: Effectiveness of Preprocessing Strategies and External Options for Improving Speech Recognition in Noise. J Am Acad Audiol, 2010; 21: 441-51.

17. Blamey PJ, James CJ, Wildi K, McDermott H, Martin LF. Adaptive dynamic range optimization sound processor. United States Patent Application, 1999 (6731767); 1-7.

18. Dawson PW, Decker JA, Psarros CE. Optimizing Dynamic range in children using the Nucleus cochlear implant. Ear Hear, 2004; 25: 230-41.

19. Patrick JF, Busby PA, Gibson PJ. The Development of the Nucleus Freedom Cochlear Implant System. Trends Amplif, 2006; 10: 175-200.

20. Wolfe J, Schafer EC, Heldner B, Mulder H, Ward E, Vincent B. Evaluation of speech recognition in noise with cochlear implants and dynamic FM. J Am Acad Audiol, 2009; 20: 409-21.

21. Spriet A, Van Deun L, Eftaxiadis K, Laneau J, Moonen M, van Dijk B et al. Speech under-standing in background noise with the two-microphone adaptive beamformer BEAM in the $\mathrm{Nu}$ cleus Freedom cochlear implant system. Ear Hear, 2007; 28: $62-72$.

22. Wolfe J, Schafer EC, John A, Hudson M. The effect of frontend processing on Cochlear Implant Performance of children. Otol Neurol, 2011; 32: 533-38.

23. Yathiraj A, Vijayalakshmi CS. Phonemically balanced wordlist in Kannada. A test developed at the Department of Audiology, AIISH, Mysore, 2005.

24. Rout A. Monosyllable speech identification test in English for Indian children. A test developed as a part of Master's dissertation, AIISH, University of Mysore, 1996.

25. Ethical Guidelines for Bio-Behavioural Research Involving Human Subjects. A publication at AIISH, Mysore; 2003.

26. ANSI S3.1. American National Standards Institute. Maximum permissible ambient noise for audiometric test rooms. ANSI S3.1 (1999). New York: American National Institute.

27. Dirks DD, Morgan DE, Dubno JR. A procedure for quantifying the effects of noise on Speech recognition. J Speech Hear Disord, 1982; 47: 114-23.

28. Finitzo-Hieber T, Tillman TW. Room acoustics effects on monosyllabic word discrimination ability for normal and hearingimpaired children. J Speech Hear Res, 1978; 21: 440-58.

29. Johnson, CE. Children's phoneme identification in reverberation and noise. J Speech, Lang, Hear Res, 2000; 43: 144-57. 